\title{
PERSONAL AND INTERPERSONAL USES OF PROFESSIONAL FOLKLORE PEREMPTORY JUROR CHALLENGES BY LORE AND IN FACT
}

\author{
Ross L. Hindman \\ Rice University
}

An attempt is made to explore the legal and non-legal (sociological) utility of the folklore of the art of juror selection to the practicing trial lawyer of the Chicago Personal Injury Bar. The lore concerning the choosing of jurors in personal injury cases may be seen as: a) useful to a lawyer in predicting juror verdict-deliberation behavior; b) useful for predicting jury verdict outcomes; and, c) useful for rationalizing the work world of the personal injury trial lawyer.

To corroborate these working hypotheses, 55 Chicago personal injury trial lawyer specialists (those spending 85 percent of their time on such cases) were interviewed with field notes recorded immediately upon termination of session. This was the exploratory phase of some research which resulted in the administering of a questionnaire for a verification-type study of the roles and values of such legal specialists. The sample was generated by the referral or reputation technique ("snowball sampling"). As far as can be determined, the universe of these lawyer-specialists was exhaug ted.

In outline, after the lore is discussed as a resource upon which the practitioner calls in his jury trial of a cause, a short overview of the folklore is presented to orient the reader as to its nature and the issues it can raise. Then a discussion follows, couched in the field interview data, considering whether the lawyer, in fact, employs this lore-based knowledge to direct his selection of jurors. An explanation is then presented to express what this investigator considers to be some important social-psychological functions of the folklore to the practitioner of the art of juror selection.

In conclusion, the lore is shown to lack agreement among practitioners as to its usefulness--the lore is proverbial, contradictory, and too extravagantly specific to be practical. Hence, it is concluded from these data that the lore yields little predictive capability about juror verdict behavior. This seemingly renders it unusable and, hence, discardable.

Nevertheless, the lore continues to flourish as a part of trial technique. The lore is discussed as having three functions for the practitioner: 1) for orientation toward the problem of selection; 2) for a posteriori rationalizing of jury verdict outcomes and juror verdict behavior; and 3) for professional communication (to laymenclients and fellow professionals--adversary or colleague) involving the demonstration and/or continuation of professional competence.

Is selecting a jury an art, a science, or a haphazard hit-or-miss proposition?

One school of thought holds that any twelve men will do, that picking a jury is a wasteful, 1 futile pastime, is subject to abuse, and should be abolished or at least curtailed.2 Disciples of this school say that all jurors are fair and impartial at least in theory. Anyway, there is no way of finding out who is fair and who is not 
merely by asking questions. In other words, there is no right or wrong way to pick a juror; although we all pride ourselves on knowing human nature and reading faces, no one really has the gift (Nizer, 1946-7 and Brody, 1957-67). One is always taking a chance; so it is reasonable, after finding out that the jury does not know the litigant or any counsel, to forego further examination and grandly accept the jury as satisfactory.

The other school argues that one is given the opportunity to pick the judges of the facts in a trial case, and this should be done with all the resourcefulness at his command (Nizen, 1946-7:63).

This investigation of the Personal Injury Bar of the Chicago Municipal Courts is interested in the posture of the latter school of thought on jury selection. What is the resource upon which the trial lawyer calls in his on-foot selection of jurors in the court room?

In this article, an attempt will be made to explore empirically the usefulness of the lore of the art of juror selection to the practicing trial attorney of the Personal Injury Bar. A short overview will be presented to orient the reader to the folklore so that a discussion can follow, whether or not, in fact, a practitioner in the courts employs it to direct his selection of jurors. Then an analysis will be presented to express what this investigator found to be some of the functions of the lore of the art of juror selection for personal injury lawyers, the practitioners.

Within the culture of the legal profession, much of the resourcefulness of trial attorneys becomes known in the lore. Many successful, and hence well-known, trial attorneys have recorded their experiences with juries throughout their years in court. From such knowledge, other trial attorneys, usually those less experienced, come to learn the ways of the juror, the judge of the facts in the cause on trial. 3

The Lore

When does a lawyer put his resourcefulness into motion? Apparently, the allimportant selection of jurors begins from the initial entry of any juror to the jury box. Attention is to be focused upon walk, speech, dress, and demeanor (Davis and Wiley, 1965:111). An attorney is urged to take note of jurors as they file into the box because the walk and posture of most men indicate their character. Specifically, the crippled or deformed is soured on the world because it has used him ill and for company's sake he would have the misery spread (Goldstein, 1935:177).

Why is it of concern to the lawyer that people may be bitter about life and hence should not sit on a jury? Why is it worth using up precious peremptory challenges to get them dismissed? The reason concerns the jurors' reaction to medical testimony and to illness in general. The juror may simply identify himself with the plaintiff because he has suffered a comparable misfortune. Lawyers know that the risk of having infirm and aged people on juries is that the defense will pay for their ills through substantial rewards to the plaintiff (Kalven, 1958:164).

Although much can be told from observing a juror enter the box, it is important to hear his voice since we do not read faces as well as voices or mannerisms. 4 Some have hesitated to believe those who talk without moving their lips because gesture or movement is a registry of feeling or emotion, and those who talk with no visible action only half believe what they say (Osborn, 1937:112).

A voir dire examination, then, is a time to watch for tell-tale signs of a person's inner feelings as he responds to the questions. Change of tone and inflection 
in the voice tell skilled counsel the type of person with whom they are dealing (Davis and Wiley, 1965:111). Specifically, a person who gives evidence of a general cockiness is inclined to make early judgments which are difficult to dislodge, and hence are Impartial judgments (Kennelly, 1965:16).

Just what can be learned about veniremen from the clues which trial attorneys talk about can be provided by the following comments on the significance of sex. Women are usually considered in the category of the emotional juror and are therefore controversial. Darrow (1936:38) had a fixed opinion that women were absolutely dependable but not for his juries. A well-known Chicago trial attorney would disagree with a theory that women are more sympathetic than men. He just does not agree with the theory, and, on that basis, has no preference (Kennelly, 1965).

Some qualify their acceptance or rejection of women on juries according to the needs of the case as they see it. An attorney wanting high damage awards leaves women off the jury because they are not people of large business affairs and are unaccustomed to thinking in terms of big sums of money (Nizer, 1946-7:61). It has been suggested by participants and observers of jury deliberations that justice may have gender. They note that women are more conservative in their awards in land condemnation cases, and are more severe on accused criminals and neglectful parents (Ryan, 1968:377). On the other hand, if counsel is representing a personable young man, he tries to seat kindly old ladies in the jury box (Appleman, 1952:129).

Women jurors, evaluated overall by the lore, are considered good, in that they usually pay more attention to the evidence, are serious, and strive to do their duty (Goldstein, 1935:158). However, it is noteworthy that in a highly limited test of the practitioners' lore through systematic observation men, as compared with women, are found to have higher participation and greater influence, satisfaction, and perceived competence for the jury task. 5

It was noted above that one observer of juries suggested not having "cocky" people on the jury because they form early opinions. Another student tells us that women are just the ideal jurors, for the converse reason: they have a pliable and responsive nature. It is a contented lawyer who takes his chances on the emancipated housewife who is content to become a decision-maker at twelve dollars per diem. ${ }^{b}$

To protect his client from the possibility of a "poor" verdict, the plaintiff's lawyer should not seat those who will be sceptical of the client's assertions, such as ex-policemen or investigators (Davis and Wiley, 1965:114).

Generally, should one put experienced jurors back in the box? Like ex-policemen and investigators, those who have heard testimony before are considered too callous, and hence, hard on the plaintiff. This is similar to the stereotypical welfare worker who, going out on the first few cases is moved to great pity, but with experience comes to treat such things as rather matter-of-fact. 7 This becomes positively known as professional objectivity. Jurors experienced at the task, like welfare workers, have probably heard the same old story or its variation before.

Plaintiffs' attorneys seem to want persons who are not experienced with pain and suffering, who will thus have a "fresh" response to the case of the plaintiff. Those who criticlze the jury system consider that if it is to be effective, the most levelheaded judges of the facts ought to be seated. We should find, therefore, the juror of previous duty in the box, who has seen attorneys "perform" before. Defense counsel will be in accord with this jury critic because the probability is higher that less of an emotional impact will be felt by the experienced to any sort of testimony 
of suffering. Likely the damage awards will not be so great from such a person. 8

Of foremost importance to Clarence Darrow was the juror quality of humanness. This could be detected by the nationality and religion of the prospective juror. Irishmen are to be seen for their emotional, kindly, and sympathetic nature. There is no warmth, however, in the Presbyterian who calmly and critically seats himself in the jury box. He knows right from wrong, although he seldom finds anything right; he is cold as the grave; get him off before others are contaminated (Darrow, 1936: 36).

Beyond the Irish, one can get sympathetic jurors by choosing those of Jewish, Slavic, Italian, French, or Spanish descent; the defense will be after the Nordic types: German, English, Scandinavian--these have a passion for enforcement of law and order (Goldstein, 1935).

The foregoing overview of the lore of the art of juror selection is intended to be a representative summary, not a systematic review of all the skills and subtleties involved in the art of juror selection; such is beyond the scope of this article ${ }^{9}$ and is a knowledgeable subject to many of our readers. Nevertheless, it does give essential insights into who ought to be picked for jury duty, according to some of the learned trial attorneys.

One of the questions central to this article is whether the lore is actually used by practicing lawyers as they go about their concern for the first step in an actual trial.

It seems logical indeed that those who are the decision-makers in a cause are to have considerable centrality in any lawyer's case; some argue that nothing could be more important (Wellman, 1937:111). Some judges consider that a juror's duty in a trial is as important, and in some ways, even more important, than theirs. In putting jury selection into perspective with other aspects of trial strategy, one commentator gave primary importance to juries, because it matters not how thorough one may have been in preparation, or how good the case is. If the wrong men to decide the case are selected, one is bound to have a mistrial or a defeat (Osborn, 1937:27; and Wellman, 1937).

This begins an argument as to whether or not the lore is actually used by a trial lawyer while he is on-foot in the courtroom selecting a jury for the cause on trial. The data from this investigation concludes that the lore is not applied in the actual selection of a jury: too many lawyers disagree over the actual type of person to be chosen for the jury task. Every veteran lawyer has his own individual and extensive catalog of preferences and dislikes depending on which side of the case he favors. He develops his personal lore by intuition and trial-and-error from years of experience and anecdotal recitations of fellow practitioners (Field, 1965:187; and interview on file with author for respondent B.H.).

At the outset, one can fathom from the above overview of the lore about juror selection that there is indeed considerable contradiction within this body of legal literature. Another suspicion is cast upon it because it is so extravagantly detailed in many places: such precision cannot be accurate, considering the current state of theory about human behavior. Anyone who has read extensively about jury selection in trial lawyer guides or texts will agree that even more confusion exists about who ought to be impanelled than is exposed by this writer.

Hence, it was suspected that the theory about jury selection was a problematic issue for the practitioner. How can one apply the "rules" of jury selection from the 
texts when they are too situation-specific, or just contradictory to the recitations of successful practitioners--presumably the role model of the aspiring trial lawyer?

Ninety-five per cent of the trial attorneys in this sample said that the lore of the art of jury selection was simply "a bunch of bunk." It really does not apply at all as a general rule. Certainly $1 \mathrm{t}$ is helpful, in that a lawyer can read how another lawyer handled part of his selection in a particular case; or how he admits he figured it out while on foot choosing the jury in the courtroom (Interviewee, W. H., officer of the American Trial Lawyers Association). The point made among most lawyers is that all the directives in the lore are specific to the situation of a particular case, and theirs is never exactly analogous. It is rather trite to say that every case is different, but this observation is a very critical issue in the choosing of the judges of the facts in a case. The nature of the particular case does count, heavily.

Treating the foregoing problem seriously, we have to admit that the type of jury and the very juror(s) chosen will be a function of much more than just the nature of the cause on trial. All the actors in the courtroom drama--the plaintiff, defendant, witnesses, and judge--will have to be accounted for in deciding whom to select. Therefore, the specific nature of the lore and its extravagant detail become virtually useless. Again, it depends on the particular witnesses in this case and the jurors (venire) available. In short, trial attorneys tell this investigator that they just cannot accept, in every instance, what the lore suggests: specifically, that when a blond is on trial, get young men on the jury. Certainly the reasons for this directive are obvious and very intuitively appealing to all our understandings of pragmatic psychology. However, the young lady in question may be cross-examined by a handsome young attorney and brought into question by another beautiful blond witness! In such a case, it may be prudent to choose a jury comprised of as many young and beautifullooking women as are available, or perhaps a group of middle-aged working-class housewives to neutralize all the uncontrollable stimuli in the courtroom, such as the young attorney and the two beautiful young ladies.

Confusion was introduced into the foregoing discussion to impress upon the reader the difficulty of relying on the lore in a particular case. The lore simply tells us that if one's client is a young lady, get as many young male jurors as possible. It does not account for all the variables.

If lawyers do indeed find the lore virtually impractical and unusable, then what is the function of the folklore in question? Discussed are three ways in which the lore functions among the members of the Personal Injury Bar: for orientation toward the problem of selection, for rationalizing verdict behavior, and for professional communication involving the demonstration of competence.

In general, the issue of orientation concerns the impact of professional perspectives upon the individual practitioner, the degree to which the ideology is incorporated into his personal belief system.

Practitioners within many professions studied have revealed that they are cognizant of the occupational perspectives and ideologies, but do not accept them. 10 For example, many prostitutes refuse to stereotype the customer, even though seeing them all as alike is one of the beliefs the prostitute is encouraged to hold when she is taught the trade (Bryan, 1966:444).

However, such perspectives still give the practitioner a posture toward problemsolving in a rational manner, when the subject-matter is known to lack much agreement and there is uncertainty for proceeding successfully. These uncertainties are dealt 
with primarily within the realm of magic; that is, every horse better has his "system" (Scott, 1968: especlally chapter 5) and cabdrivers play up to the customer to manipulate the tip (Davis, 1959). In other words, a lawyer's system of lore for selecting a jury may parallel that of the Winnebago hunter who first shoots an arrow down an empty path before taking up the hunt. This, he explains, kills the deer's spirit so that next the body of the beast can be slain. Why that particular site? Because the physical conditions suitable for the kill have determined it that site, based on a wealth of practical experience. What if the first arrow were shot down another path? Would that be sufficient preliminaries? The Indian promptly, with amusement, denies the possibility (recounted in Greer, 1969:49 from Radin).

Perhaps the amused aspect of a trial lawyer's response to my inquiry about jury selection techniques was contained in his becoming anecdotal about specific instances. Furthermore, a wealth of practical experience may be the reas on for a lawyer denying that any fat woman will do for a certain type of case. It must be "the fat woman that I choose."

Closely related to the above function of the folklore, both theoretically and practically, is the usefulness of being able to rationalize juror verdict behavior. That is, any practitioner's typologies of clients stem in large part from the attempt to order experience, reduce uncertainty, and further the calculability of the verdict deliberations of the jurors. It is questionable, of course, how accurate or efficient the lawyer's typologies are. For, as has often been remarked, stereotypes and typologies have a way of imparting symmetery and regularity to behavior which are, at best, only crudely approximate in reality (Davis, 1959:163). Too often the cabdriver's "sport" turns out in the end of the ride to be a non-tipping "stiff"; or, the smiling woman juror was the only one for the defendant, and the eleven men wanted to find in favor of the young male plaintiff with a high damage award!

This investigator found that lawyers want to decide in their rather fleeting relationship with jurors, before it begins or ends, what can be counted on by way of jury verdict deliberations. There exists among lawyers an extensive typology of veniremen in which the attributes imputed to each type have a certain predictive value as regards verdicts. Lawyers want something from jurors by way of a pay-off; namely, a verdict returned in favor of their client and consequently a contingent fee based on the damage award. Lawyers have to deal with the daily routine of work (picking juries) and solving problems, which consequently involve making mistakes. Therefore, the individual practitioner learns a particular perspective or paradigm for doing these things (Hughes, 1958: 461). Mistakes are made every day, but as one lawyer relates, one just tries to keep them to a manageable number, "perhaps eighty rather than a hundred" (Interviewee W. H.).

The lore of juror selection is as such a perspective or paradigm for handling trial routines and mistakes. The investigator's consideration of the occupation of betting on horses led to this suspicion. Practitioners there have a solution to the problem of coping rationally with the complexities of picking a winner. To maintain the belief of rational choice in picking the horses, the player need only give a reasonable account as to why the horse that he selected lost, and why the horse that finished first won. Reasonable accounts as to why his horse lost are easy to come by, and remind those of us who frequent the courts of comparable hallway exchanges. The distance of the race was a little too long or a little too short; the condition of the track was slightly off, or was too hard; and so on (Scott, 1968: 90-1).

A lawyer similarly refers to the verdict he received from a jury within the boundaries of his professional perspective, part of the folklore about jurors: "If 
I had one peremptory left, I would have gotten rid of that oyerweight woman. It was obvious that she tore my fashion-model client all to hell in that jury room. "11. That is, after the fact, the trial lawyer uses acceptable perspectives to render his decisions and their outcomes understandable, somewhat to himself, and more importantly, to other professionally significant persons. Thus, the trial lawyer finds an interpretation in a contradictory pattern and in this way explains any verdict behavior. In short, any juror trait or its opposite may serve as a warrant to account for the results of any trial and its jury deliberations.

In the last analysis, the lawyer's folklore, with its typology of jurors, does not further to any marked degree his control of the verdict.

Implicit in the foregoing insights into the rationalizing function of the folklore is the usefulness of it as a vehicle for professional communication and demonstration of competence. A practitioner is able to communicate with others by use of the lore's facility in making understandable the outcomes of trials, even though it has little practical value in the choice of jurors.

Ideologies? Professional perspectives? They are used and unused, rationally based for practitioners but interpreted contrarily between individuals? Puzzling as this may seem, there is a path through this social-psychological maze. Socialization into an occupation, or initiation into a moral career, involves learning the ideologies and professional perspectives during the apprenticeship period. Call girls learn how to run their business: how to get customers, how to handle each type, and the usefulness of their activity to the customer and to society (Bryan, 1966:448). The horse-racing regular is taught how to use the Racing Form to glean information which can be combined with that picked up by "trained" senses at the paddock about the horse trainer and the jockey (Scott, 1968:81-112).

It appears, then, that during the initial months of a career, the ideologies and professional perspectives are taught by a "trainer." Thereafter, the practitioners know the ideology but do not endorse it. Therefore, it is reasonable to assume that such a perspective as the folklore of juror selection serves a variety of purposes for both the individual trial man and his related audiences, and does so with varying degrees of importance over time.

\section{Conclusion}

In this study of juror selection I have attempted to show the nature of the lore about choosing jurors and its utility. An overview of that body of legal literature was presented to demonstrate that it does not have much internal coherence. That is, there exist great contradictions among lawyers as to the attributes that a juror ought to possess to be impanelled in a personal injury trial case. This conclusion among those commenting on juror selection through peremptory challenge leads one to suspect that the information about selection, contained in the lore, is of little use to the practitioner. This question, of course, is an empirical one.

My data suggest that indeed the lore of juror selection is quite difficult to use, and the practitioner therefore considers it irrevelevant and a "lot of bunk." He sees it as useless, in the sense that it does not mark out clear routes to obtaining the type of jury a trial man needs for his purposes. However, it is not useless, in the sense that it has considerable utility or function within the profession. These latent functions of the folklore about jury behavior were discussed as being those of: orientation to the problem or task of selection, a rationalization of verdict behavior, and a ground for certain professional communications and for handling the issue of professional competence. 
Orientations or occupational perspectives are important to those being initiated; they provide some stance against a very burdensome task which has no rational base for proceeding toward a solution and hence toward professional success. It appears, in light of the current data, that such orientations are learned during the apprenticeshfp into the craft of selection for trial and the initial few months of attempting jury selection. It is doubtful that it remains of equal importance throughout the ensuing development of one's career as a trial lawyer.

Nevertheless, lore continues its usefulness whenever one is called upon to understand and perhaps explain jury verdict behavior. Any outcome from a selection of jurors can be understood in terms of the lore. Any behavior trait of a juror, or its opposite, can be understood through the lore.

Such utility provides the basis for a great deal of communication among fellow professionals. They can understand and be understood, somewhat because the lore is a flexible, shared, occupational perspective. If successful with jurors' behavior and verdict outcomes, then the lawyer has mastered the nuances of the art of juror selection, to which the lore alludes through its specifics.

In closing, choose a juror by the way you feel about the person--this is a necessary condition. If you have a feeling about a juror that may lead the two of you not to get on easily as the trial unfolds, challenge. No trial lawyer would really deny that:

I just want to find out if those people in the jury box resent me in any way. That's the thing I'm worried about most. It doesn't matter what the hell they tell you, it's how they say it to you that you got to get a gut feelin' for. Then decide whether they are with you or against; on your jury or off.

Granted, that feeling may not guarantee that the juror you keep will be a good juror, but it is primary:

By asking them those rote questions you heard I get a gut feeling for the juror by his answers. That is, his attitudes toward things come out in the way he gives his answers. Like that woman from the A\&P; I just made up that story about the fall-down case in her store which involved the manager that I supposedly knew in order to have a pretense to get rid of her. I just didn't like her, that's all. If you don't make up an acceptable reason for the others why one of them is being dismissed then they sometimes take offense to you. Of course, the whole idea of this process is to get persons who are not against you in the trial. You want persons who will accept the arguments you present in court. So I just attach significance to the questions I ask in so far as they feel our the attitudes of prospective jurors toward me (an interviewee).

The sufficient conditions for the good juror in particular cases will be developed by the practitioner as experience teaches. Needless to say, if you do not gain this skill or art, you will not be practicing trial law. This is what my respondents meant by "some have it and some don't." You either possess a workable skill for handling people and develop it, or you work at another specialty where you have the talent to handle the sufficient conditions for getting on. 12

The lore does not contain sufficient direction for proceeding successfully with juror selection. The persistence of these juror typologies has perhaps as much to do with the trial lawyer's a posteriori reconstructions and rationalizations of juror 
deliberation behavior and verdicts than it does with predictive efficiency.

\section{Footnotes}

*I am grateful to Howard S. Becker, Ray Mack, Richard "Red" Schwartz, and John T. Walton for commenting on a draft of the larger study from which this paper is taken. For discussing this research project with me, I thank Scott Greer, John Kitsuse, Ann E. Lennarson, and Victor Rosenblum. My gratitude is expressed, for financial aid, to: Canada Council (doctoral fellow); Northwestern University (fellow in sociology); and Russell Sage Foundation, Law and Social Sciences Fellowship.

${ }^{1}$ For a summary of the debate over the jury system, see Kalven, Harry Jr., "The Dignity of the Civil Jury." "At the core of the criticism are the beliefs that the jury not determine its verdict on the basis of the evidence and that the members of the jury do not have the special skills and training that are needed to make a rational decision about the kinds of disputes with which they are confronted" (Rita James Simon).

2 Nizer, Louis, "The Art of the Jury Trial," 1946-7, is part of the text of his address to the New York County Lawyers' Association, in 1946. In 1ight of the argument in this paper it is interesting to note that Nizer said that the jury selection process was the only part of a case where he depended, at all, on his intuition.

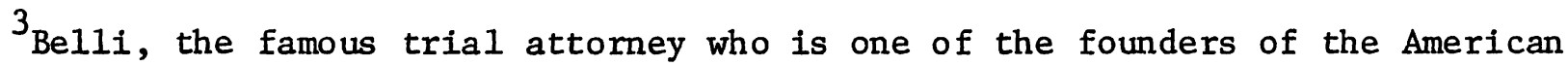
Trial Lawyers' Association, not only wrote texts on how to try cases but travelled extensively, teaching lesser attorneys his skills. For a description of his teaching travels, see Chapter 1 of Belli, Melvin, Ready for the Plaintiff, 1956. His fourvolume trial manual is Modern Trials, 1954.

${ }^{4}$ Nizer, 1946-7. It is interesting to note that the area of non-verbal communication is now seriously under experimental investigation by a very able researcher, John B. Bryan. In a conversation, Bryan informed me that he is finding a consistency with which persons telegraph various sorts of information, non-verbally, when communicating.

${ }^{5}$ Strodbeck, et al., 1957:713-719. This finding came out of the famous University of Chicago Jury Study directed by Kalven and Zeisel. The design of this particular phase cited was experimental. That is, juries were chosen by the regular process, minus the voir dire, and read the transcripts of a trial. Then they withdrew to the jury room for deliberation and were tested afterwards, as to their perceptions about satisfaction, competence, and deliberation influence.

${ }^{6}$ Ryan, 1968. A defense, who wants conservative-type jurors, said he selected the higher-class suburban housewife merely because he could not get her husband, who, "if he has anything on the ball, gets himself excused from jury duty." (Interview with H. M., on file with author).

${ }^{7}$ Goldstein, 157. This process of moving from the emotive response to a matterof-fact posture becomes solidified in a principle known as "professional objectivity."

8 Jerome Frank holds quite a critical view of the American jury. See his Law and the Modern Mind, 1930, and Osborn, 1937:8. 
${ }^{9}$ Such a summary is included in the larger study, undertaken by the author, on the Personal Injury Bar.

${ }^{10}$ For a general theoretical statement about the professions, see Hughes, 1958. Some of the theoretical and substantive detail of occupations can be found in: Bryan, 1966:441-450; and Davis, 1959:158-165.

${ }^{11}$ Such comments are so numerous among the conversations of trial attorneys that they do not require documentation. However, this is a sample of the numerous comments of equal bearing on the subject, on file with the author.

${ }^{12}$ Some salient issues will be discussed in a forthcoming paper on "Juries: Lawyers' Status, Financial and Professional."

\section{References}

Appleman, John Alan

1952 Success ful Jury Trials. Indianapolis.

Belli, Melvin

1956 Ready for the Plaintiff. Indianapolis: Bobbs-Merrill.

1954 Modern Trials. Indianapolis: Bobbs-Merrill.

Brody, Abraham

1957 "Selecting a jury--Art or blindman's buff?" Criminal Law Review 4.

Bryan, James $\mathrm{H}$.

1966 "Occupational ideologies and individual attitudes in call girls." Social Problems (Spring): 441-50.

Darrow, Clarence

1936 "Attorney for the defense." Esquire 38 (May).

Davis, Bruce and Richard E. Wiley

1965 "Thoughts on jury selection." Trial Lawyer's Guide 9.

Davis, Fred

1959 "The cabdriver and his fare: Facets of a fleeting relationship." American Journal of Sociology 65 (September): 158-65.

Field, Lyman

1965 "Voir dire examination--A neglected art." University of Missouri at Kansas City Law Review 33 (Summer).

Frank, Jerome

1930 Law and the Modern Mind. New York.

Golds tein, Irvin

1935 Trial Technique. Chicago.

Greer, Scott

1969 The Logic of Social Inquiry. Chicago: Aldine. 
Hughes, Everett C.

1958 Men and Their Work. Glencoe: Free Press.

Kalven, Harry Jr.

1968 "The dignity of the civil jury." Pp. 293-313 in Rita James Simons (ed.), The Sociology of Law. San Francisco: Chandler.

1958 "The jury, the law and the personal injury damage award." Ohio State Law Journal 19.

Kennelly, John H.

1965 "Jury selection in a civil case." Trial Lawyer's Guide 9.

Nizer, Louis

1946- "The art of the jury trial." The Cornell Law Quarterly 32.

Osborn, Albert S.

1937 The Mind of the Juror. Albany, New York.

Ryan, Joseph E.

1968 "Does justice have gender?"' American 118 (March 23).

S cott, Marvin

1968 The Racing Game. Chicago: Aldine.

Simons, Rita James

1967 The Jury and the Defense of Insanity. Boston: Little, Brown and Co.

Strodbeck, Fred L., Rita M. James, and Charles Hawkins

1957 "Social status in jury deliberations." American Sociological Review 22 (December) : 713-9.

Wellman, Francis

1937 Day in Court. New York. 